\title{
Faktor-faktor Penentu Tarif Biaya Audit Eksternal (Audit Fee) pada Perusahaan Non-Keuangan
}

\author{
Robertus Nakacama Erik Tat, Dewi Murdiawati* \\ STIE Perbanas Surabaya, J. Nginden Semolo No.34-36, Surabaya, Jawa Timur, \\ Indonesia \\ *(dewi.murdiawati@perbanas.ac.id)
}

Riwayat Artikel:

Tanggal diajukan:

23 April 2020

Tanggal diterima:

12 Juni 2020

Tanggal dipublikasi daring: 25 Juni 2020

Kata kunci: audit fee; dewan komisaris independen; kompleksitas perusahaan; koneksi politik; ukuran Kantor Akuntan Publik

\section{Pengutipan:}

Tat, R. N. E. \& Murdiawati, D. (2020). Faktor-faktor Penentu Tarif Biaya Audit Eksternal (Audit Fee) pada Perusahaan Non-Keuangan. JIA (Jurnal Ilmiah Akuntansi), 5 (1), 177195

Keywords: audit fee; company complexity; independent board commissioner; political connection; public accounting firm size

\section{ABSTRAK}

Hasil-hasil penelitian terdahulu masih menunjukkan adanya inkonsistensi terkait faktor-faktor penentu besaran audit fee. Penelitian ini bertujuan untuk menguji pengaruh koneksi politik perusahaan, keberadaan dewan komisaris independen, kompleksitas perusahaan, ukuran Kantor Akuntan Publik (KAP), dan profitabilitas perusahaan terhadap tarif biaya audit eksternal (audit fee) pada perusahaan-perusahaan non-keuangan yang terdaftar di Bursa Efek Indonesia periode tahun 2016-2018. Sampel ditentukan secara purposif dan menghasilkan sejumlah 130 perusahaan sebagai sampel. Teknik analisis data yang digunakan adalah analisis regresi linear berganda. Hasil penelitian menunjukkan bahwa koneksi politik perusahaan, kompleksitas perusahaan, dan ukuran Kantor Akuntan Publik (KAP) berpengaruh positif terhadap audit fee. Sementara itu, keberadaan dewan komisaris independen dan profitabilitas perusahaan tidak berpengaruh terhadap audit fee.

\begin{abstract}
The results of previous studies still indicate inconsistencies related to the determinants of the audit fee. The aims of this research is to examine the effect of company political connection, the existence of independent board commissioner, company complexity, public accounting firm size, and company profitability on the audit fee in non-financial companies listed in the Indonesia Stock Exchange on 2016-2018. The sampling technique that used in this research was purposive sampling and produced the number of sample was 130 companies. The data were analyzed by using multiple linear regression analysis. The results show that political connection, company complexity and public accounting firm size positively influence the audit fee. Meanwhile, the existence of independent board commissioner and company profitability do not affect the auditfee.
\end{abstract}




\section{PENDAHULUAN}

Laporan keuangan suatu perusahaan sangat penting dalam memberikan informasi kepada manajemen sebagai pengambil keputusan dan kepada stakeholder sebagai pemegang saham. Oleh sebab itu, laporan keuangan harus diperiksa oleh pihak yang mempunyai independensi, relevansi dan kredibilitas yang tinggi untuk meningkatkan kualitas laporan keuangan yang dilaporkan oleh manajemen. Selain itu, hal tersebut juga perlu dilakukan dalam rangka menghindari kesalahan penyajian laporan keuangan yang mengakibatkan kerugian pemakai laporan keuangan yang lain.

Auditor eksternal pada kantor akuntan publik merupakan pihak yang professional yang bebas dari intervensi pemakai laporan keuangan, baik itu manajemen maupun stakeholder. Akuntan eksternal merupakan pihak yang profesional, sehingga dengan demikian perusahaan harus memberikan fee kepada akuntan tersebut atas jasa audit yang telah diberikan kepada perusahaan.

Audit fee adalah biaya yang dibebankan oleh auditor dalam proses audit kepada perusahaan yang diaudit. Penentuan audit fee dapat didasarkan pada kesepakatan antara auditor dan auditee berdasarkan waktu yang dibutuhkan, jumlah staf dan jenis auditnya (El-Gammal, 2012). Di Indonesia, tidak terdapat aturan yang mengatur tentang audit fee yang diterima oleh auditor atas jasa audit yang diberikan, yang ada hanya peraturan yang diterbitkan oleh Institut Akuntan Publik Indonesia (2008) tentang panduan penetapan besaran audit fee. Surat Keputusan tersebut dikeluarkan untuk seluruh anggota IAPI yang melakukan praktik akuntan publik mengenai besaran imbalan jasa audit yang sewajarnya dan pantas diterima auditor dalam melakukan audit.

Besaran audit fee akan dipengaruhi oleh dua hal yaitu, atribut klien dan atribut auditor (Yulio, 2016). Atribut klien yang diuji dalam penelitian ini yaitu koneksi politik perusahaan, kompleksitas perusahaan, dewan komisaris independen, dan profitabilitas perusahaan. Sedangkan atribut auditor dalam penelitian ini yaitu ukuran kantor akuntan publik.

Purwoto (2011) menyatakan bahwa perusahaan berkoneksi politik ialah perusahaan yang dengan cara tertentu mempunyai ikatan secara politik atau mengusahakan kedekatan dengan politisi atau pemerintah. Gomes (2014) menambahkan bahwa perusahaan 
yang mempunyai koneksi politik mempunyai hubungan bisnis yang eksklusif dan mempunyai akses yang istimewa pada setiap kebijakan pemerintah.

Dewan komisaris independen atau dewan komisaris merupakan pihak yang tidak mempunyai kepentingan dan hubungan dengan perusahaan. Dewan komisaris yang independen di dalam perusahaan bertugas untuk melakukan pengawasan terhadap kinerja manajemen, termasuk mengawasi pelaporan keuangan perusahaan. Adanya pengawasan dari dewan komisaris yang independen berdampak pada tata kelola perusahan yang baik dan juga mengurangi salah saji pelaporan laporan keuangan.

$$
\text { Kompleksitas perusahaan }
$$
menurut Fitriana (2018) adalah hal yang berkaitan dengan kerumitan transaksi yang ada di perusahaan. Kerumitan tersebut dapat berasal dari transaksi menggunakan mata uang asing, jumlah anak dan cabang perusahaan, serta juga adanya operasi bisnis di luar negeri.

Kantor Akuntan Publik (KAP) adalah suatu bentuk organisasi akuntan yang memperoleh izin sesuai dengan peraturan perundangundangan, yang berusaha di bidang pemberian jasa professional dalam praktek akuntan dibagi menjadi dua, yaitu KAP yang berafiliasi Internasional (Big Four) dan tidak berafliasi Internasioanl (Non-Big Four). Menurut Immanuel \& Yuyetta (2014), kantor Akuntan Publik yang termasuk dalam Big Four dipercaya mempunyai efektifitas dan efisiensi serta terbiasa memberikan jasa audit kepada banyak klien, serta lebih berhati-hati dalam mendeteksi kesalahan sehingga dapat menghasilkan laporan keuangan dengan kualitas yang lebih baik.

Profitabilitas

perusahaan digunakan untuk menilai kinerja manajemen dalam memanfaatkan sumber daya yang digunakan secara efektif dan efisien. Keuntungan yang diperoleh dapat dilihat dari laporan keuangan yang dibuat oleh perusahaan. Perusahaan yang memiliki keuntungan yang tinggi akan mengungkapkan lebih banyak informasi untuk memperlihatkan keuntungan yang diperoleh. Pengungkapan lebih banyak informasi digunakan untuk meyakinkan para pemegang saham terkait kinerja perusahaan sehingga dapat memperkuat posisi perusahaan.

Hasil penelitian yang telah dilakukan sebelumnya menghasilkan hasil yang berbeda-beda tentang faktor-faktor yang mempengaruhi audit fee. Seperti penelitian Pradana 
\& Purwanto (2016) yang menemukan bahwa variabel koneksi politik tidak mempunyai pengaruh signifikan terhadap audit fee. Sementara itu, Khan, Devi, \& Meng (2015) dalam penelitiannya menyatakan bahwa perusahaan dengan direktur yang memiliki koneksi politik berpengaruh signifikan terhadadap audit fee yang dikenakan pada perusahaan tersebut. Untuk penelitian yang dilakukan oleh Chandra (2015) menyatakan bahwa dewan komisaris independen tidak berpengaruh terhadap audit fee.

Namun demikian, hasil yang berbeda dikemukakan oleh Naser \& Hassan (2016) yang dalam penelitiannya menemukan bahwa dewan komisaris independen mempunyai pengaruh signifikan pada audit fee. Untuk variabel independen berupa kompleksitas perusahaan dan profitabilitas juga memberikan hasil yang belum konsisten. Penelitian yang dilakukan Cristansy \& Ardiati (2017) mendapati bahwa kompleksitas perusahaan tidak mempunyai pengaruh signifikan terhadap audit fee. Di lain, pihak penelitian yang dilakukan Yulio (2016) menyatakan bahwa kompleksitas perusahaan berpengaruh signifikan positif pada audit fee.

Musah

penelitiannya

profitabilitas
(2017) dalam menyatakan perusahaan berpengaruh signifikan terhadap audit fee. Namun demikian, penelitian yang dilakukan Naser \& Hassan (2016) menyatakan bahwa profitabilitas perusahaan tidak berpengaruh signifikan terhadap audit fee.

Penelitian ini dilatarbelakangi oleh penelitian Rusmanto \& Waworuntu (2015) yang dalam penelitiannya semua variabel independennya menggunakan atribut klien, tanpa memperhatikan atribut auditor yang berupa salah satunya ukuran Kantor Akuntan Publik (KAP). Menurut Yulio (2016), untuk memperhitungkan audit fee juga perlu memperhitungkan faktor di luar perusahan, yaitu berupa atribut auditor. Selain itu untuk sampel perusahaan diperluas menjadi seluruh perusahaan non keuangan yang terdaftar di Bursa Efek Indonesia (BEI). Selain itu hasil penelitian tentang variabel ukuran Kantor Akuntan Publik (KAP) terhadap audit fee juga beragam.

Penelitian Fitriana (2018) menunjukkan bahwa ukuran Kantor Akuntan Publik (KAP) berpengaruh positif terhadap audit fee. Hasil penelitian ini juga didukung oleh penelitian Cristansy \& Ardiati (2017) yang menyatakan bahwa ukuran Kantor Akuntan Publik (KAP) berpengaruh signifikan terhadap 
audit fee. Tetapi penelitian Naser \& Hassan (2016) menyatakan ukuran Kantor Akuntan Publik (KAP) tidak mempunyai pengaruh signifikan terhadap auditfee.

\section{TELAAH LITERATUR \\ PERUMUSAN HIPOTESIS}

DAN

\section{Teori Keagenan (Agency Theory)}

Teori yang digunakan dalam penelitian ini adalah Teori Keagenan. Teori keagenan dikemukakan oleh Jensen \& Meckling (1976) yang menjelaskan adanya konflik kepentingan antara manajemen selaku agen dan pemilik serta entitas lain dalam kontrak (misal investor) selaku principal. Principal ingin mengetahui informasi termasuk aktivitas perusahaan dengan cara meminta laporan karena dengan laporan tersebut principal dapat mengetahui dan menilai kinerja manajemen. Namun yang sering terjadi kecendrungan manajemen untuk membuat laporan keuangan kelihatan baik, sehingga kinerjanya dianggap baik.

Untuk mengurangi asimetri informasi dan meminimalisir kecurangan yang sering dilakukan oleh manajemen maka laporan keuangan manajemen tersebut harus dievaluasi oleh pihak ketiga yang independen dalam hal ini adalah auditor eksternal. Auditor eksternal dianggap pihak ketiga yang dianggap menjembatani principal dan agent. Penggunaan auditor eksternal untuk melakukan pengawasan terhadap manajemen perusahaan dapat menimbulkan agency cost, berupa audit fee.

\section{Pengaruh Koneksi Politik terhadap Audit fee}

Perusahaan yang berkoneksi politik adalah perusahaan yang dengan cara tertentu mempunyai ikatan politik atau mengusahakan kedekatan dengan politik atau pemerintah. Koneksi politik bisa memberikan dua pilihan, menguntungkan perusahaan atau merugikan perusahaan. Menurut Gomez (2014), perusahaan yang mempunyai koneksi politik mempunyai hubungan bisnis yang eksklusif dan mempunyai akses yang istimewa pada setiap kebijakan pemerintah. Hubungan bisnis yang eksklusif dan akses yang istimewa yang dimiliki perusahaan kepada pemerintah seringkali dicurigai oleh principal sebagai tindakan nepotisme antara pemerintah dan agen.

Untuk meyakinkan principal, perusahaan yang mempunyai koneksi politik akan menggunakan KAP Big Four. KAP Big Four dipercaya dapat memberikan audit dengan kualitas yang lebih baik. Khan et al. (2015) 
dalam penelitiannya menyatakan bahwa variabel koneksi politik mempunyai pengaruh terhadap audit fee.

Berdasarkan pembahasan sebelumnya, maka dirumuskan hipotesis pada penelitian ini sebagai berikut:

$\mathrm{H}_{1}$ : Koneksi politik yang dimiliki perusahaan berpengaruh terhadap auditfee

\section{Pengaruh Dewan Komisaris Independen terhadap Audit fee}

Teori Keagenan menjelaskan bahwa konflik antara principal dan agent disebabkan karena adanya asimetri informasi yang diterima principal dan agen. Agen sebagai pengendali perusahaan memiliki informasi yang lebih baik dan lebih banyak dibandingkan dengan principal. Dewan komisaris yang independen dapat mengurangi asimetri informasi dan membatasi tindakan manipulasi laporan keuangan yang dilakukan oleh agen.

Mengurangi tindakan manipulasi laporan keuangan dapat dilakukan dengan memastikan bahwa pelaporan laporan keuangan yang dilakukan oleh agen sesuai dengan Pernyataan Standar Akuntansi Keuangan (PSAK) sehingga akan mengurangi risiko audit yang akan dihadapi oleh akuntan eksternal.
Semakin kecil risiko yang dihadapi oleh auditor eksternal akan berdampak pada audit fee yang bisa berkurang pula. Naser \& Hassan (2016) dalam penelitiannya menyatakan bahwa independensi dewan komisaris mempunyai pengaruh terhadap audit fee.

Berdasarkan pembahasan sebelumnya, maka dirumuskan hipotesis pada penelitian ini sebagai berikut:

$\mathrm{H}_{2}$ : Dewan komisaris independen berpengaruh terhadap auditfee

\section{Pengaruh Kompleksitas Perusahaan terhadap Audit fee}

Teori Keagenan menjelaskan akan muncul potensi konflik kepentingan antara agen dan principal. Potensi konflik kepentingan ada karena principal tidak dapat memonitor aktivitas agen sehari-hari secara terus-menerus. Tindakan monitor ini berguna untuk memastikan bahwa agen bertindak sesuai dengan keinginan principal. Principal tidak dapat memonitor aktivitas agen secara terus-menerus karena banyaknya jumlah anak dan cabang perusahaan yang membuat perusahaan menjadi kompleks. Semakin kompleks perusahaan klien, maka akan semakin besar risiko dan tingkat kesulitan yang akan dihadapi oleh auditor karena itu memerlukan 
pekerjaan audit yang lebih banyak. Hal tersebut akan berdampak pada audit fee yang akan diterima oleh auditor. Naser \& Hassan (2016) dan Yulio (2016) menemukan bahwa kompleksitas perusahaan berpengaruh terhadap audit fee.

Berdasarkan pembahasan sebelumnya, maka dirumuskan hipotesis pada penelitian ini sebagai berikut:

$\mathrm{H}_{3}$ : Kompleksitas perusahaan berpengaruh terhadap audit fee

\section{Pengaruh Ukuran KAP terhadap Audit fee.}

Teori Keagenan menjelaskan bahwa terjadi konflik kepentingan antara agen dan principal. Adanya konflik kepentingan membuat principal menggunakan pihak ketiga untuk melakukan pengawasan terhadap agen. Pihak ketiga dalam hal ini adalah auditor independen yang dianggap mampu menjembatani agent dan principal. Principal lebih mempercayai pengawasan dilakukan kantor akuntan Big Four karena dianggap lebih berhati-hati dalam mendeteksi kesalahan sehingga dapat menghasilkan laporan keuangan dengan kualitas baik (Immanuel \& Yuyetta, 2014). Hal tersebut akan berpengaruh terhadap jasa professional audit yang diberikan karena apabila perusahaan tersebut diaudit oleh KAP Big Four maka audit fee yang diberikan perusahaan akan lebih besar dibandingkan dengan perusahaan yang diaudit oleh KAP Non-Big Four. Sinaga \& Rachmawati (2018) serta Fitriana (2018) dalam penelitiannya menunjukan bahwa ukuran KAP berpengaruh terhadap audit fee.

Berdasarkan pembahasan sebelumnya, maka dirumuskan hipotesis pada penelitian ini sebagai berikut:

$\mathrm{H}_{4}$ : Ukuran KAP berpengaruh terhadap audit fee

\section{Pengaruh Profitabilitas Perusahaan terhadap Audit fee}

Teori Keagenan menjelaskan bahwa konflik keagenan disebabkan karena agen tidak memenuhi kebutuhan dan kesejahteraan principal (Jensen \& Meckling, 1976). Perusahaan dengan tingkat profitabilitas yang tinggi akan menghasilkan laba dan deviden yang besar. Dari laba setelah pajak tersebut sebagian dibagikan sebagai deviden kepada para pemegang saham dan sebagian lagi ditahan di perusahaan (laba ditahan). Agar para pemegang saham dapat menikmati dividen yang besar, maka manajemen akan berusaha untuk memperoleh laba yang sebesar-besarnya guna meningkatkan

kemampuan 
membayar dividen untuk memenuhi keinginan dan kesejahteraan para pemegangsaham.

Perusahaan yang memiliki profitabilitas yang tinggi akan diaudit secara ketat untuk memastikan tidak terjadi kesalahan penyajian dalam laporan keuangan. Pekerjaan audit yang semakin ketat untuk memastikan tidak terjadi kesalahan penyajian dalam laporan keuangan akan menyebabkan semakin tinggi audit fee yang diterima oleh auditor. Hal tersebut akan berpengaruh tehadap biaya audit fee yang dibebankan kepada perusahaan. Musah (2017) dalam penelitiannya menyatakan bahwa profitabilitas perusahaan berpengaruh terhadap audit fee.

Berdasarkan pembahasan sebelumnya, maka dirumuskan hipotesis pada penelitian ini sebagai berikut:
$\mathrm{H}_{5}$ : Profitabilitas berpengaruh terhadap audit fee

\section{METODE}

Penelitian ini merupakan penelitian kuantitatif yaitu metode penelitian yang berdasarkan pada filsafat positivisme, digunakan untuk meneliti pada populasi suatu sampel tertentu, teknik pengambilan sampel pada umumnya random, pengumpulan data menggunakan instrumen penelitian, analisis data bersifat kuantitatif atau statistik dengan tujuan untuk menguji hipotesis yang telah ditetapkan (Sugiyono, 2015).

\section{Definisi Operasional dan Pengukuran Variabel}

Audit fee

Audit fee merupakan jumlah imbalan jasa professional yang dipandang sesuai dengan kinerja yang diberikan oleh auditor (Jusup, 2014). Audit fee kemudian akan diukur dengan menggunakan logaritma natural dari audit feel Cristansy \& Ardiati, 2017)

Koneksi Politik Perusahaan

Perusahaan berkoneksi politik ialah perusahaan yang dengan caracara tertentu mempunyai ikatan secara politik atau mengusahakan adanya kedekatan dengan politisi atau pemerintah (Purwoto, 2011). Koneksi politik perusahaan kemudian dalam penelitian ini diukur menggunakan variabel dummy. Dimana kategori (1) untuk perusahaan yang mempunyai pimpinan perusahaan (CEO, presiden, wakil presiden, ketua atau sekretaris) adalah anggota parlemen, menteri, orang yang pernah mempunyai jabatan penting di kementerian dan orang yang berkaitan erat dengan 
politikus atau partai politik dan kategori (0) untuk perusahaan yang tidak mempunyai pimpinan perusahaan (CEO, presiden, wakil presiden, ketua atau sekretaris) adalah anggota parlemen, menteri, orang yang pernah mempunyai jabatan penting di kementerian dan orang yang berkaitan erat dengan politikus atau partai politik.

\section{Dewan Komisaris Independen}

Dewan komisaris independen yang terpisah dari pihak manajemen memiliki tugas untuk mengawasi kinerja manajemen, termasuk mengawasi pelaporan keuangan agar sesuai dengan PSAK. Variabel independensi dewan komisaris kemudian dalam penelitian ini dapat dilihat dengan membandingkan jumlah anggota dewan komisaris independen dengan jumlah anggota dewan komisaris (Sukaniasih \& Tenaya, 2016).

\section{Kompleksitas Perusahaan}

Kompleksitas perusahaan berkaitan dengan dengan kerumitan transaksi yang terjadi di peusahaan. Kerumitan tersebut dapat berasal dari transaksi menggunakan mata uang asing, jumlah anak dan cabang perusahaan, dan juga adanya operasi bisnis di luar negeri. Dalam penelitian ini kompleksitas perusahaan dapat ditunjukan dengan jumlah anak dan cabang perusahaan yang dimiliki perusahaan klien (Fitriana, 2018)

\section{Ukuran KAP}

Kantor Akuntan Publik (KAP) adalah suatu bentuk organisasi akuntan yang memperoleh izin sesuai dengan peraturan perundangundangan, yang berusaha di bidang pemberian jasa professional dalam praktek akuntan. Dalam penelitian ini ukuran KAP diukur menggunakan variabel dummy, dimana angka (1) diberikan untuk KAP Big Four dan (0) diberikan untuk KAP non-Big Four (Chandra, 2015).

\section{Profitabilitas Perusahaan}

Profitabilitas adalah kemampuan perusahaan memperoleh laba terkait dengan penjualan, dan kapasitas pasar. Variabel ini diukur dengan menggunakan Return on Assets (ROA). ROA merupakan salah satu bentuk analisis rasio profitabilitas yang digunakan untuk mengukur efisiensi perusahaan dalam mengelola asetnya guna menghasilkan laba. Return on assets (ROA) secara matematis dirumuskan sebagai berikut (Sudana, 2011):

$$
\text { Return on Assets }(\mathrm{ROA})=\frac{\text { Earning After Tax }}{\text { Total Assets }}
$$




\section{Populasi dan Sampel}

Populasi yang digunakan dalam penelitian ini adalah semua perusahaan non-keuangan yang terdaftar di Bursa Efek Indonesia periode 2016 sampai dengan 2018. Sampel adalah bagian dari jumlah dan karekteristik yang dimiliki oleh populasi tersebut (Sugiyono, 2015). Teknik pengambilan sampel yang digunakan dalam penelitian ini adalah purposive sampling.

Kriteria-kriteria yang digunakan dalam penelitian ini adalah bahwa perusahaan-perusahaan tersebut merupakan perusahaan-perusahaan non-keuangan yang terdaftar di Bursa Efek Indonesia periode 2016-2018 serta melaporkan audit fee berturutturut pada laporan tahunan selama periode 2016-2018. Berdasarkan kriteria tersebut maka diperoleh 130 perusahaan non-keuangan dengan keseluruhan jumlah sampel sebanyak 390 karena penelitian dilakukan selama tiga tahun.

\section{Metode Pengumpulan Data}

Pada penelitian ini data yang digunakan adalah data sekunder. Dalam penelitian ini peneliti mengambil data berdasarkan dokumen-dokumen sumber berupa laporan tahunan perusahaan yang didapat dari Bursa Efek Indonesia. Teknik pengumpulan data yang digunakan dalam penelitian ini adalah strategi arsip. Strategi arsip (archival) adalah data yang dikumpulkan dari catatan atau basis data yang sudah ada (Hartono, 2017).

\section{Teknis Analisis Data}

Teknik analisis data menggunakan analisis regresi linear berganda. Analisis ini digunakan untukmenentukan hubungan antara variabel dependen dengan variabel independen (Ghozali, 2016).

\section{Uji Statistik Deskriptif}

Metode analisis ini memberikan gambaran tentang sebuah data yang dilihat dari rata-rata (mean), standart deviasi, varians, maksimum, minimum, sum, range, kuartosis dan sawness (kemiringan distribusi) menurut (Ghozali, 2016). Analisis deskriptif digunakan untuk mendeskripsikan variabel-variabel yang digunakan dalam penelitian ini. Analisis deskriptif dilakukan dengan menggunakan statistik deskriptif yang menghasilkan nilai rata-rata, maksimum, minimum, dan standar deviasi untuk mendeskripsikan variabel penelitian sehingga secara kontekstual mudah dimengerti.

\section{Uji F}

Uji F digunakan untuk mengetahui ada tidaknya pengaruh 
secara bersama-sama variabel bebas terhadap variabel terkait, yakni dengan membandingkan $F$ hitung dengan $F$ tabel dengan tingkat kepercayaan 95\% dan signifikasi 0,05. Jika $F$ hitung lebih besar dari $F$ tabel, maka hipotesis diterima. Jika $\mathrm{F}$ hitung lebih kecil dari F tabel, maka hipotesis ditolak (Ghozali, 2016)

\section{Uji Koefisien Determinasi $R^{2}$}

Uji koefisien determinasi $R^{2}$ digunakan untuk mengukur seberapa besar persentase pengaruh varibel independen terhadap variabel dependen (Ghozali, 2016)

\section{Uji $t$}

Uji $t$ dilakukan untuk mengetahui apakah semua variabel independen secara parsial berpengaruh terhadap signifikan terhadap variabel dependen. Jika nilai statistik Hosmer and Lemeshow's goodness of Fit Test sama dengan atau kurang dari 0,05 maka hipotesis nol ditolak dan apabila nilai statistik Hosmer and Lemeshow Goodness of fit lebih besar daripada 0,05 maka hipotesis nol tidak ditolak. Ini berarti model mampu memprediksi nilai observasinya atau dikatakan model dapat diterima karena sesuai dengan data observasinya (Ghozali, 2016).

Uji Regresi Linear Berganda
Menggunakan analisis regresi linear berganda karena variabel independen dalam penelitian ini lebih dari satu. Analisis ini digunakan untuk menentukan hubungan antara variabel dependen dengan variabel independen (Ghozali, 2016). Model persamaan statistik yang digunakan untuk menguji hipotesis tersebut sebagai berikut :

$$
\begin{gathered}
\mathbf{Y}=\mathbf{a}+\boldsymbol{\beta}_{1} \mathbf{X}_{1}+\boldsymbol{\beta}_{2} \mathbf{X}_{2}+\beta_{3} \mathbf{X}_{3}+\beta_{4} \mathbf{X}_{4}+ \\
\beta_{5} \mathbf{X}_{5}
\end{gathered}
$$

\section{HASIL DAN PEMBAHASAN}

\section{Analisis Statistik Deskriptif}

Hasil analisis statistik deskriptif variabel dependen yaitu audit fee dan variabel independen yaitu koneksi politik perusahaan, dewan komisaris independen, kompleksitas perusahaan, ukuran Kantor Akuntan Publik, dan profitabilitas dengan melihat nilai minimum, maksimum, rata-rata (mean) dan standar deviasi dari tabel hasil pengujian data. Hasil analisis statistik deskriptif pada penelitian ini bisa dilihat di Tabel 1 dan Tabel 2.

\section{Uji Hipotesis}

Pada analisis regresi linear berganda, digunakan untuk menguji hubungan variabel dependen dengan variabel independen. Hasil dari analisis regresi linear berganda pada penelitian ini ada pada Tabel 3. 
Tabel 1. Statistik Deskriptif

\begin{tabular}{lcrccc}
\hline & $N$ & Minimum & Maximum & Mean & Std. Deviation \\
\hline FA & 390 & 17,66 & 23,949 & 20,4 & 1,126 \\
DKI & 390 & 0,167 & 1.0 & 0,389 & 0,094 \\
KP & 390 & 0 & 65 & 9,71 & 12,534 \\
Profit & 390 & $-0,807$ & 0,921 & 0,04302 & 0,129465 \\
\hline
\end{tabular}

Tabel 2. Analisis Frekuensi Ukuran KAP

\begin{tabular}{lcc}
\hline & Frequency & Percent \\
\hline KAP Non Big Four & 218 & 55.9 \\
KAP Big Four & 172 & 44.1 \\
Total & 390 & 100 \\
\hline
\end{tabular}

Tabel 3. Hasil Uji Kolmogorov-Smirnov

\begin{tabular}{lr}
\hline & Unstandardized Residual \\
\hline$N$ & 60 \\
Test Statistic & 0,073 \\
Asymp. Sig. (2-tailed) & $0,200^{\mathrm{c}, \mathrm{d}}$ \\
\hline
\end{tabular}

Berdasarkan tabel di atas menunjukkan bahwa variabel koneksi politik perusahaan, kompleksitas perusahaan, dan ukuran KAP berpengaruh terhadap audit fee karena nilai signifikansinya kurang dari 0,05. Sedangkan variabel dewan komisaris independen dan profitabilitas perusahaan tidakberpengaruh karena nilai signifikansinya lebih dari 0,05, maka didapatkan persamaan regresi berganda sebagai berikut. Dengan demikian persamaan regresinya adalah:
Audit fee $=19,759+0,534 \mathrm{X} 1-0,597$

$\mathrm{X} 2+0,026 \mathrm{X} 3+0,996 \mathrm{X} 4+0,139$

$\mathrm{X} 5+\mathrm{e}$

\section{Uji F}

Uji $F$ ini bertujuan untuk mengetahui apakah model dari penelitian fit atau tidak fit dan mengetahui apakah seluruh variabel independen memiliki pengaruh terhadap variabel dependen.

Pada penelitian ini diketahui bahwa nilai $\mathrm{F}$ hitung sebesar 55,218 dengan tingkat signifikansi sebesar $0,000<0,05$ maka dapat disimpulkan bahwa model regresi fit dan dapat 
Tabel 4. Hasil Uji $t$

\begin{tabular}{llcc}
\hline Model & $T$ & Sig. \\
\hline 1 (Constant) & 96,400 & 0,000 \\
& Koneksi Politik & 5,657 & 0,000 \\
Dewan Komisaris Independen & $-1,225$ & 0,221 \\
Kompleksitas Perusahaan & 7,867 & 0,000 \\
Ukuran KAP & 10,295 & 0,000 \\
& Profitabilitas & 0,383 & 0,702 \\
\hline
\end{tabular}

Sumber: Data dianalisis

digunakan untuk mengetahui pengaruh variabel koneksi politik, dewan komisarisindependensi, kompleksitas perusahaan, ukuran KAP, dan profitabilitas perusahaan secara bersama-sama mempengaruhi variabel audit fee.

\section{Uji Koefisien Determinasi $\mathbf{R}^{2}$}

Pada penelitian ini diketahui bahwa nilai adjusted $\mathrm{R}$ square sebesar 0,411. Hal ini menunjukan bahwa variabel independen yang terdiri dari koneksi politik, dewan komisarisindependensi, kompleksitas perusahaan, ukuran KAP, dan profitabilitas mampu menjelaskan variabel audit fee sebesar 41,1\% dan sisanya 58,9 \% dijelaskan variabel lain diluar variabel independen yang diteliti. Selain itu nilai adjusted $\mathrm{R}$ square sebesar 0,411 memperlihatkan bahwa kemampuan variabel independen dalam menjelaskan variabel dependen rendah karena $\leq 50$ persen.

\section{Uji t}

Uji ini bertujuan untuk menunjukkan seberapa jauh pengaruh satu variabel independen secara individual dalam menerangkan variasi variabel dependen. Hasil pengujian disajikan pada Tabel 4.

Pada penelitian ini, dapat dikatakan sebagai berikut: Variabel koneksi politik perusahaan berpengaruh terhadap audit fee, variabel ini memiliki nilai signifikansi 0,000 < 0,05, (2) Variabel dewan komisaris independen tidak berpengaruhterhadap audit fee, variabel ini memiliki nilai signifikansi 0,221 > 0,05, (3) Variabel kompleksitas perusahaan berpengaruh terhadap audit fee, variabel ini memiliki nilai signifikansi $0,000<0,05,(4)$ Variabel ukuran KAP berpengaruh terhadap audit fee, variabel ini memiliki nilai signifikansi $0,000<0,05,(5)$ Variabel profitabilitas tidak berpengaruh terhadap audit fee, variabel ini memiliki nilai signifikansi $0,000<0,05$. 


\section{Pembahasan Hasil Penelitian}

Pengaruh Koneksi Politik Perusahaan terhadap Audit Fee

Variabel koneksi politik perusahaan berpengaruh terhadap audit fee. Hal ini didukung dari data frekuensi koneksi politik perusahaan, dimana perusahaan yang mempunyai pimpinan perusahaan (CEO, presiden, wakil presiden, ketua atau sekretaris) adalah anggota parlemen, menteri, orang yang pernah mempunyai jabatan penting di kementerian dan orang yang berkaitan erat dengan politikus atau partai politik memakai jasa audit KAP Big Four sehingga biaya audit atau audit fee yang diberikan perusahaan juga semakin besar.

Hal ini seperti pada PT. Indosat Tbk yang memberikan audit fee diatas rata-rata perusahaan lainnya yaitu sebesar Rp 25.174.000.000. Audit fee yang semakin besar dikarenakan PT. Indosat Tbk menggunakan jasa KAP Big Four untuk melakukan audit atas laporan keuangan perusahaan. Selain itu PT. Indosat Tbk juga mempunyai koneksi politik yang terdapat pada Bapak Heru Pambudi yang menjabat sebagai dewan komisaris pada PT. Indosat Tbk, selain itu Bapak Heru saat ini menjabat sebagai Direktur Jenderal Bea dan Cukai, Kementerian Keuangan Republik Indonesia. Perusahaan yang mempunyai koneksi politik merupakan perusahaan risk taker. Perusahaan risk taker adalah perusahaan yang menggunakan pengaruhnya untuk memperoleh akses yang lebih mudah untuk mendapatkan fasilitas yang diberikan pemerintah, contoh pinjaman. Pinjaman yang diperoleh akan digunakan untuk mengatasi masalah keuangan di dalam perusahaan dan perusahaan seperti ini risiko gagal bayarnya tinggi. Kemungkinan gagal bayar yang besar akan menyebabkan risiko audit semakin tinggi sehingga audit fee juga meningkat.

Hasil penelitian ini konsisten dengan penelitian yang dilakukan oleh Khan et al. (2015) yang menyatakan bahwa koneksi politik berpengaruh terhadap audit fee. Penelitian ini bertentangan dengan penelitian yang dilakukan oleh (Pradana \& Purwanto, 2016)yang menyatakan bahwa koneksi politik tidak berpengaruh terhadap auditfee.

Pengaruh Dewan Komisaris Independen terhadap Audit Fee

Variabel dewan komisaris independen tidak berpengaruh terhadap audit fee. Hal ini menunjukan bahwa dewan komisaris independen yang banyak maupun dewan komisaris independen yang sedikit di dalam perusahaan tidak mempengaruhi besaran imbalan jasa 
atau audit fee yang diberikan perusahaan kepada auditor. Besaran audit fee yang diberikan perusahaan kepada auditor diatur dalam surat keputusan Institut Akuntan Publik Indonesia (2008) tentang dasar penetapan audit fee menyatakan bahwa dalam menetapkan imbalan jasa audit, akuntan publik harus memperhitungkan kebutuhan klien, tugas dan tanggung jawab menurut hukum, independensi, tingkat keahlian, waktu, serta dasar penetapan audit fee. Dasar penetapan audit fee ditentukan berdasarkan kesepakatan antara KAP dengan komite audit perusahaan. Hal ini yang yang menjadi penyebab jumlah dewan komisaris independen yang dimiliki perusahaan tidak berpengaruh terhadap audit fee karena penentuan besaran imbalan jasa audit atau audit fee memperhitungkan kebutuhan klien, tugas dan tanggung jawab menurut hukum, independensi, tingkat keahlian, waktu, serta dasar penetapan audit fee sedangkan tugas dari dewan komisaris independen adalah mengawasi kinerja manajemen sehinggatidak berpengaruh terhadap penentuan auditfee.

Hasil penelitian ini konsisten dengan penelitian yang dilakukan oleh Chandra (2015) dan Sukaniasih \& Tenaya (2016) yang menyatakan bahwa independensi dewan komisaris tidak berpengaruh terhadap audit fee. Penelitian ini bertentangan dengan penelitian yang dilakukan oleh Naser \& Hassan (2016) yang menyatakan bahwa independensi dewan komisaris berpengaruh terhadap audit fee.

\section{Pengaruh Kompleksitas Perusahaan} terhadap Audit Fee

Variabel kompleksitas perusahaan berpengaruh terhadap audit fee. Hal ini didukung dari data deskriptif yang menunjukan perusahaan yang memiliki jumlah anak perusahaan terbanyak yaitu PT. Indika Energy Tbk dengan jumlah anak perusahaan sebanyak 65 anak perusahaan mempunyai audit fee diatas rata-rata perusahaan lain yaitu sebesar Rp 1.529.800.000 sedangkan perusahaan yang tidak mempunyai anak perusahaan seperti PT. WahanaProntural Tbk mempunyai audit fee dibawah perusahaan lainnya yaitu sebesar Rp46.750.000. Adanya anak perusahaan menuntut perusahaan indukuntuk menyusun laporan keuangan konsolidasi. Hal tersebut akan meningkatkan kompleksitas proses audit yang harus dikerjakan oleh auditor. Proses audit yang semakin kompleks memerlukan pekerjaan audit yang lebih banyak dan juga tingkat kesulitan yang dihadapi auditor akan semakin tinggi. 
Hal tersebut akan menambah audit fee yang akan diterima oleh auditor.

Hasil penelitian ini konsisten dengan penelitian yang dilakukan oleh Yulio (2016) dan Naser \& Hassan (2016) yang menyatakan bahwa kompleksitas perusahaan berpengaruh terhadap audit fee. Hasil penelitian ini bertentangan dengan penelitian yang dilakukan oleh Cristansy \& Ardiati (2017) dan Rusmanto \& Waworuntu (2015) yang menyatakan bahwakompleksitas perusahaan tidak berpengaruh terhadap audit fee.

Pengaruh Ukuran Kantor Akuntan Publik terhadap Audit Fee

Variabel ukuran KAP
berpengaruh terhadap audit fee. Hal ini terlihat dari perusahaan yang diaudit menggunakan KAP Big Four membayar audit fee lebih besar dibandingkan dengan perusahaan yang menggunakan KAP non Big Four. Seperti yang terjadi pada PT. Indosat Tbk, PT. Indocement Tunggal Prakasa Tbk, PT. Semen Indonesia, dan beberapa perusahaan yang memberikan imbalan jasa audit atau audit fee diatas rata-rata perusahaan lainnya. Audit fee yang semakin besar dikarenakan perusahaan menggunakan jasa KAP Big Four untuk melakukan audit atas laporan keuangan perusahaan. KAP yang berafiliasi dengan KAP Big Fourdipercaya dapat memberikan audit dengan kualitas yang lebih baik. Hal ini dikarenakan auditor di KAP Big Four memiliki jam terbang lebih tinggi, klien lebih banyak, efektifitas dan efisiensi yang lebih baik dibandingkan KAP non Big Four(Immanuel \& Yuyetta, 2014). Menurut (Fitriana, 2018)dengan pengalaman dan keahlian yang dimiliki, KAP Big Four akan menetapkan fee yang ekstra atas jasa yang mereka berikan. Hal tersebut akan sejalan dengan audit fee yang ditetapkan.

Hasil penelitian ini konsisten dengan penelitian yang dilakukan oleh Sinaga \& Rachmawati (2018), Cristansy \& Ardiati (2017), Yulio (2016), Musah (2017), Naser \& Hassan (2016), dan Khan et al. (2015) yang menyatakan bahwa ukuran KAP berpengaruh terhadap audit fee. Penelitian ini bertentangan dengan penelitian yang dilakukanoleh (Suharli \& Nurlaelah, 2008)yang menyatakan bahwa ukuran KAP tidak berpengaruh terhadap audit fee.

Pengaruh Profitabilitas Perusahaan terhadap Audit Fee

Variabel profitabilitas tidak berpengaruh terhadap audit fee. Hal ini didukung dengan hasil analisis deskriptif yang menunjukan bahwa 
perusahaan yang mengalami kerugian memberikan audit fee diatas rata-rata perusahaan lainnya seperti yang terjadi pada PT. Atlas Resources Tbk sedangkan perusahaan yang mengalami keuntungan yang tinggi memberikan audit fee dibawah ratarata perusahaan lainnya seperti yang terjadi pada PT. Merck Tbk tetapiterdapat juga perusahaan yang mengalami keuntungan yang tinggi memberikan audit fee diatas rata-rata perusahaan lainnya seperti yang terjadi pada PT. Plaza Indonesia Realty sedangkan perusahaan yang mengalami kerugian memberikan audit fee dibawah rata-rata perusahaan lainnya seperti yang terjadi pada PT. Fortune Indonesia Tbk. Hal ini menunjukan bahwa perusahaan dengan keuntungan yang tinggi maupun kerugian yang tinggi akan menggeluarkan audit fee yang sama. Peraturan Institut Akuntan Publik Indonesia (2008) tentang dasar penetapan audit fee menyatakan bahwa dalam menetapkan imbalan jasa audit, akuntan publik harus memperhitungkan kebutuhan klien, tugas dan tanggung jawab menurut hukum, independensi, tingkat keahlian, waktu, serta dasar penetapan audit fee.

Hasil penelitian ini konsisten dengan penelitian yang dilakukan oleh Naser \& Hassan (2016) dan
Rusmanto \& Waworuntu (2015) yang menyatakan bahwa profitabilitas perusahaan tidak berpenagruh terhadap audit fee yang diterima auditor. Penelitian ini bertentangan dengan penelitian yang dilakukan oleh Musah (2017) yang menyatakan bahwa profitabilitas perusahaan berhubungan dengan audit fee yang diterima auditor.

\section{KESIMPULAN, IMPLIKASI DAN KETERBATASAN PENELITIAN}

Penelitian bertujuan untuk menguji pengaruh koneksi politik perusahaan, dewan komisaris independen, kompleksitas perusahaan, ukuran kantor akuntan publik (KAP) dan profitabilitas terhadap audit fee pada seluruh perusahaan non-keuangan yang terdaftar di Bursa Efek Indonesia tahun 2016-2018. Kontribusi utama pada penelitian ini memberikan bukti empiris terkait penelitian koneksi politik perusahaan, dewan komisaris independen, kompleksitas perusahaan, ukuran kantor akuntan publik (KAP) dan profitabilitas terhadap audit fee.

Hasil penelitian ini menunjukkan bahwa koneksi politik perusahaan, kompleksitas perusahaan, dan ukuran kantor akuntan publik (KAP) mempunyai pengaruh positif terhadap audit fee 
pada perusahaan non-keuangan yang terdaftar di Bursa Efek Indonesia tahun 2016-2018. Sedangkan variabel dewan komisaris independen dan profitabilitas tidak mempunyai pengaruh terhadap audit fee.

Penelitian ini, sayangnya, hanya menggunakan sampel perusahaan non-keuangan yang terdaftar di Bursa Efek Indonesia (BEI) dan belum mencakup semua sektor perusahaan yang listing di Bursa Efek Indonesia (BEI). Selain itu untuk penelitian selanjutnya menambahkan variabelvariabel independen lainnnya mengingat nilai adjusted $R^{2}$ sebesar 41,1\% yang masih dibawah 50\%.

\section{REFERENSI}

Chandra, M. O. (2015). Pengaruh Good Corporate Governance, Karakteristik Perusahaan dan Ukuran KAP Terhadap Fee Audit Eksternal. Jurnal Akuntansi Bisnis, 13(26), 174-194.

Cristansy, J., \& Ardiati, A. Y. (2017). Pengaruh Kompleksitas Perusahaan, Ukuran Perusahaan, dan Ukuran KAP terhadap Fee Audit pada Perusahaan Manufaktur yang Terdaftar di BEI Tahun 20122016. MODUS-Jurnal Ekonomi Dan Bisnis, 30(2), 198-211.

El-Gammal, W. (2012). Determinants of Audit Fees: Evidence from Lebanon. International Business Research, 5(11), 136-145.

Fitriana. (2018). Pengaruh Risiko Litigasi, Corporate Governance, Karakteristik Perusahaan, dan Karakteristik Auditor terhadap
Audit fee (Studi pada Perusahaan yang Terdaftar di Bursa Efek Indonesia tahun 2014-2017). Universitas Muria Kudus.

Ghozali, I. (2016). Aplikasi Analisis Multivariete Dengan Program IBM SPSS 23 (Edisi 8). In Universitas Diponegoro. Semarang: Badan Penerbit Universitas Diponegoro.

Gomez, E. T. (2014). Malaysia's Political Economy Ownership and Control of the Corporate Sector. In S. Lemière (Ed.), Misplaced Democracy: Malaysian Politics and People (pp. 245-282). Selangor, Malaysia: Strategic Information and Research Development Centre.

Hartono, J. (2017). Metodologi Penelitian Bisnis (6th ed.). Yogyakarta: BPFE.

Immanuel, R., \& Yuyetta, E. N. A. (2014). Analisis Faktor-faktor yang Mempengaruhi Penetapan Audit Fee (Studi Empirik Pada Perusahaan Manufaktur di BEI). Diponegoro Journal of Accounting, 3(3), 816-827.

Institut Akuntan Publik Indonesia. Surat Keputusan Ketua Umum IAPI

Nomor:KEP.024/IAPI/VII/2008

Tentang Kebijakan Penentuan Fee Audit. , (2008).

Jensen, M. C., \& Meckling, W. H. (1976). Theory of the firm: Managerial Behavior, Agency Costs and Ownership Structure. Journal of Financial Economics, 13, 305-360. https://doi.org/10.1016/0304405X(76)90026-X

Jusup, A. H. (2014). Auditing (Pengauditan Berbasis ISA). Yogyakarta: Sekolah Tinggi Ilmu Manajemen YPKN.

Khan, N. I., Devi, S. S., \& Meng, C. W. 
(2015). Politically Connected Firms and External Audit Fees in Malaysia: An Internal Audit Function Perspective. Malaysian Accounting Review (MAR), 14(1), 65-80.

Musah, A. (2017). Determinants of Audit fees in a Developing Economy: Evidence from Ghana. Journal of Academic Research in Business and Social Sciences, 7(11), 716-730.

Naser, K., \& Hassan, Y. M. (2016). Factors Influencing External Audit Fees of Companies Listed on Dubai Financial Market. International Journal of Islamic and Middle Eastern Finance and Management, 9(3), 346-363. https://doi.org/10.1108/IMEFM01-2015-0007

Pradana, S. E. N., \& Purwanto, A. (2016). Faktor-faktor Penentu Tarif Biaya Audit Eksternal pada Perusahaan yang Terdaftar di Bursa Efek Indonesia (Studi Empiris terhadap Perusahaan yang terdaftar di Bursa Efek Indonesia). Diponegoro Journal of Accounting, 5(3), 22-32.

Purwoto, L. (2011). Pengaruh Koneksi Politis, Kepemilikan Pemerintah dan Keburaman Laporan Keuangan terhadap Kesinkronan dan Risiko Crash Harga Saham. Universitas Gajah Mada.

Rusmanto, T., \& Waworuntu, S. R. (2015). Factors Influencing Audit Fee in Indonesian Publicly Listed Companies Applying GCG. Procedia - Social and Behavioral Sciences, 172, 63-67.

Sinaga, E. A., \& Rachmawati, S. (2018). Besaran Fee Audit pada Perusahaan yang Terdaftar di Bursa Efek Indonesia. Media Riset Akuntansi, Auditing \& Informasi, 18(1), 19-34.
Sudana, I. M. (2011). Manajemen Keuangan Perusahaan. Jakarta: Erlangga.

Sugiyono. (2015). Metode Penelitian Pendidikan (Pendekatan Kuantitatif, Kualitatif dan R\&D). Bandung: Alfabeta.

Suharli, M., \& Nurlaelah, N. (2008). Konsentrasi Auditor dan Penetapan Fee Audit: Investigasi pada BUMN. Jurnal Akuntansi Dan Auditing Indonesia, 12(2), 133-148.

Sukaniasih, N. K., \& Tenaya, A. I. (2016). Pengaruh Komposisi Dewan Komisaris, Karakteristik Komite Audit, dan Manajemen Laba terhadap Fee audit. EJurnal Akuntansi Universitas Udayana, 15(3), 2161-2187.

Yulio, W. S. (2016). Pengaruh Konvergensi IFRS, Komite Audit, dan Kompleksitas Perusahaan terhadap Fee Audit. Jurnal Akuntansi Bisnis, 15(29), 77-92. 